\title{
The Rubberbandits' Guide to Satire: Absurdism and Social Commentary in a Cross-Media Environment
}

\author{
Faye Mercier \\ University of Amsterdam, The Netherlands
}

Copyright (c) 2021 by Faye Mercier. This text may be archived and redistributed both in electronic form and in hard copy, provided that the author and journal are properly cited and no fee is charged for access.

\begin{abstract}
This paper argues that through an engagement with cross-media hybridity, Irish comedy duo The Rubberbandits have established a dynamic cross-media forum that aims to restore the Irish public's capacity for critical social and political engagement. Central to this process is The Rubberbandits' ability to use their absurdist satire as a foundational tool that can serve as the basis of this cultural forum, while also facilitating the negotiation of social and political issues across a variety of media. Given that this cultural forum exists across different media, platforms, and formats, this paper sets out to analyse the various ways in which the duo have adapted their satirical style to suit the demands of these different media forms, and what implications this process of adaption has had on their work. Beginning with an analysis of the social and critical functions of satirical comedy more broadly, this paper will then focus on the specific brand of satirical social commentary employed by The Rubberbandits, paying particular attention to the role of absurdity in their critical engagement with prominent issues facing Irish society. As this paper will demonstrate, by embracing the hybridity of the crossmedia environment, all the while maintaining their absurdist satirical style, The Rubberbandits have established a dynamic and carnivalesque cross-media forum that aims to restore the Irish public’s capacity for critical social and political engagement.
\end{abstract}

Key Words. Cross-Media Specificity, Satire, Social Commentary, Absurdism, Carnivalesque, Cultural Forum, The Rubberbandits

Resumen. Este artículo sostiene que, a través de un compromiso con la hibridación de medios, el dúo de comedia irlandés The Rubberbandits ha establecido un foro dinámico que tiene como objetivo restaurar la capacidad del público irlandés con el compromiso crítico social y político. Un elemento central de este proceso es la manera en que The Rubberbandits utiliza la comedia satírica como una herramienta fundamental que sirve de base para un foro cultural de este tipo y permite que los problemas sociales y políticos irlandeses relevantes se negocien a través de una variedad de medios. Dado que este foro cultural existe en diferentes medios, plataformas y formatos, este artículo propone analizar las diversas formas en que el dúo ha adaptado su estilo satírico a las demandas de estos diferentes medios, y qué implicaciones tiene este proceso de adaptación. Comenzando con un análisis de las funciones sociales y críticas de la comedia 
satírica de manera amplia, este artículo se centrará posteriormente en el tipo específico de comentario satírico de tipo social empleado por The Rubberbandits, prestando especial atención al papel del absurdo en su compromiso crítico con temas candentes a los que se enfrenta la sociedad irlandesa. Este artículo tiene como objetivo demostrar cómo funciona la sátira social en un entorno entre medios, y cómo los Rubberbandits han adaptado su formato específico de comentario social a las estructuras de las diferentes plataformas para seguir siendo efectivos, con las implicaciones que tiene esto para la crítica social y el compromiso político.

Palabras clave. Especificidad inter-media, sátira, comentario social, medios, absurdo, carnivalesco, foro cultural, The Rubberbandits.

\section{Introduction}

Following the viral success of their song "Horse Outside" (8 December 2010), Irish comedy duo The Rubberbandits have become regular fixtures in both the Irish and British entertainment industries. The duo, consisting of Blindboy Boatclub and Mr Chrome (Dave Chambers and Bob McGlynn respectively) rose to prominence as a hip-hop comedy group, with their absurdist lyrics and music videos engaging with common Irish social issues in a satirical manner. Their consequent work with the Irish national broadcaster Raidío Teilifís Éireann (RTÉ) has allowed them to develop their own particular genre of satirical social commentary, focusing in particular on Irish history, questions of national identity, and contemporary social issues. Although their work is largely satirical in nature, The Rubberbandits have taken a more serious tone on a number of matters in recent years, and have become prominent social commentators in Irish society. Central to the popularity of The Rubberbandits, both as satirists and as social commentators, is their expansive cross-media presence. Since their debut, the duo have found success across a variety of formats, platforms, and mediums, establishing a kind of cross-media forum that utilises multiple media avenues to entice audiences into a space of critical social and political engagement. Most notable, however, is that the specific configuration of satire and serious commentary they employ tends to shift depending on the particularities of the medium, platform, or format with which they engage. As this paper will demonstrate, by embracing the hybridity of the cross-media environment, all the while maintaining their absurdist satirical style, The Rubberbandits have established a dynamic and carnivalesque cross-media forum that aims to restore the Irish public's capacity for critical social and political engagement.

\section{The Rubberbandits, Absurdist Satire, and Irish Society}

Formed in the early 2000s, The Rubberbandits first came to public attention with a series of recorded prank phone calls that were circulated via CD in their home town of Limerick. These prank calls were soon uploaded to Myspace before finding their way onto several Irish radio shows (Vaughan and Moriarty). The duo became a stage act in 2007 and made their television debut in 2010 with a weekly segment on RTÉ's Republic of Telly (RTÉ Two, 2009-2017), a satirical magazine show that parodied the Irish and British television industries. Their appearances on Republic of Telly ranged from music videos to mock news reports, and their time on the show solidified their absurdist style and distinctive Limerick personas. It was during this period that The Rubberbandits had their breakthrough moment, becoming household names following the release of their song "Horse Outside" in December 2010. The song's music video, which initially aired on an episode of Republic of Telly, became somewhat of a viral sensation in Ireland, reaching 1.5 million views within 15 days of its upload to YouTube, and became the second most tweeted video at the time of its release (Carr). The "Horse Outside" song and music 
video encapsulate the absurdist satirical style of The Rubberbandits, portraying a working-class Limerick wedding where the song's protagonist, Mr. Chrome, attempts to beat out other suitors in wooing a bridesmaid. Mr. Chrome ultimately succeeds in impressing the bridesmaid when she learns that he has horse and not a car, and the music video depicts in humorous detail Mr. Chrome's efforts to prove himself against the other suitors. The first inklings of their absurdist comedy come when we see Mr. Chrome and Blindboy Boatclub on screen, wearing their signature plastic bag masks as they sing sexually explicit and profanity-laced lyrics while standing at a church altar. Soon Blindboy is gyrating down the church aisles as Mr. Chrome makes obscene gestures towards his rival suitors, telling them that their respective souped-up vehicles hold no allure when compared to his "horse outside". Once he has successfully wooed the bridesmaid, Mr. Chrome and Blindboy are joined by the other wedding guests as they mock the other failed suitors outside the church, with the bridesmaids now wearing horse masks and dancing in celebration alongside Mr. Chrome.

For many viewers this was their first introduction to the absurdist humour of The Rubberbandits, as well as the caricature-like Limerick personas of Mr. Chrome and Blindboy Boatclub. Dubbed "Gas Cuntism” by the duo, The Rubberbandits have described their satirical style as a kind of dark, yet insightful comedy, and have openly referenced Dadaism as a source of inspiration (Boatclub). ${ }^{1}$ In particular, the duo have argued that their absurdist satirical comedy is the only appropriate means of responding to a society characterised by hopelessness and pain (Boatclub). More specifically, The Rubberbandits see their work as a means of addressing issues relating to contemporary Irish experience, particularly following the Celtic Tiger and the post-2008 financial downturn. Rather than attempt to accurately reflect this reality, however, the duo instead seek to strip Irish society down to its "basic absurdity" through their work, highlighting issues of poverty, discrimination, and social divisions (Boatclub). For The Rubberbandits, the absurdism of their satirical style works to expose dominant cultural and political narratives as irrational, and lays bare the inconsistencies that have come to characterise Irish society and its political sphere. The themes explored in "Horse Outside," for example, turn contemporaneous Celtic Tiger notions of success on their head, with modern signifiers of material wealth such as cars being rejected in favour of more traditional, rural, and workingclass symbols of stability such as urban horse ownership. Not only does the song suggest that a valorisation of material wealth will not guarantee personal success, but it also pokes fun at notions of a trendy and prosperous Celtic Tiger Ireland by calling attention to communities who have never fit into this dominant image. In this way, The Rubberbandits use absurdist humour to point out to their audience the kinds of inconsistencies and absurd generalisations that lie at the heart of dominant Irish social and political discourses.

Of course, the expository and corrective functions of both comedy and satire have been well-documented, and the critical nature of The Rubberbandits' work is not in itself particularly unique. Bergson, for example, demonstrates how laughter has an intrinsically corrective social function in that it serves to call attention to the shortcomings of others, thus encouraging them to improve. Laughter, he argues, is characterised by an "aim of general improvement", one that prompts the individual to recognise their own unconscious behaviours and faults so that they can then correct themselves (Bergson 16-7). This is, in short, how comedy can be understood as a corrective social tool; by generating laughter, comedy is able to draw attention to the shortcomings of others in a light-hearted manner comedy can encourage others to reflect on, re-evaluate, and potentially adjust their unconscious behaviours. Satirical comedy, however, attempts a more critical and somewhat subversive approach to this same corrective goal. Satirical comedy is both deliberate and calculated in its attempts to highlight the inconsistent and/or questionable tendencies of others. In this sense, satire is an intentional attempt to emancipate the collective consciousness of society by exposing and challenging "naive beliefs and [...] popular delusions" (Boland 443). This is achieved through various, oftentimes 
aggressive means, with "caricature [...] mimicry, defacement, belittlement, exaggeration, and deformation" common techniques employed by satirists to expose and question the behaviour of others (Brillenburg 118). Through an exaggeration or distortion of reality these techniques draw attention to the potentially problematic implications of certain social issues and political errors, which risk going unnoticed in a critically disengaged or politically alienated society (Crines; Scripnic and Popa). It is through laughter that satirical comedy attempts to expose popular delusions to its audience, consequently prompting a rational engagement with the target of its derision.

It is here that the absurdist tendencies of The Rubberbandits are most notable. If the aim of satire is to position the comic as superior by laughing at others, then, through an engagement with absurdist comedy, satire can not only point to the illogical actions of others, but is also able to position itself and the comic as a source of logical interpretation (Kaplan). The absurdist satire of The Rubberbandits seeks to counter, if not cancel out entirely, what the duo refer to as the "basic absurdity" of contemporary Irish society itself (Boatclub). By engaging with absurdist humour in order to lay bare the inconsistencies and contradictions of Irish society, The Rubberbandits consequently hope to position themselves as a voice of reason for their audience. These efforts are most pronounced in their exploration of the experiences of younger Irish generations and their place within Irish society, specifically those who grew up during or were born after the post-2008 financial downturn. The personas embodied by the duo are particularly notable here, as they serve to interrogate the behaviours and stereotypes attributed to young, working-class Irish men and the social challenges they face in a society gripped by recession and uncertainty. While both Chambers and McGlynn come from middle-class Limerick backgrounds, their Rubberbandits' personas are readily identifiable as working-class and urban through both attire and speech. Importantly, their exaggerated accents are specific to working-class areas of Limerick City, seen as some of the most disadvantaged communities in the country having long suffered a reputation for gangland crime and violence (Cowan). ${ }^{2} \mathrm{By}$ adopting these working-class personas the duo attempt to speak to a broader society that felt increasingly abandoned by the political system following the 2008 financial crash, revealing to them that the purported prosperity and progress of Irish society was never a reality for all. In doing so, The Rubberbandits make the Irish public's previous faith in its political and economic systems all the more jarring by exposing how the nation's progress has always required the exclusion and abandonment of others.

Typically dressed in tracksuits and other clothing items associated with working class communities, the personas of Blindboy Boatclub and Mr Chrome are an interrogation of the stereotypes associated with working-class Irish males, and through an emphasis on their Limerick City backgrounds the duo are calling for a recognition of the social barriers and political infrastructures that have generated these stereotypes. The plastic bags worn as masks by the duo to preserve their anonymity are worth also noting here. The bags often come from smaller, local newsagents (which are largely located in or near working-class housing estates), or from fast-food restaurants and budget grocery stores. Shopping bags from larger, up-market chains are never used. Not only do these plastic-bag-come-balaclavas mock the gangland reputation of Limerick City, as well as republican stereotypes, they also provide commentary on the barriers faced by its young inhabitants. ${ }^{3}$ These young, faceless working-class males are overlooked and stigmatised by Irish society, identified only by their economic situation, which hinders their ability to improve their social status.

Alongside an examination of the stereotypes and difficult social realities experienced by members of Limerick's working class community, The Rubberbandits also explore the widespread discrimination faced by Ireland's Traveling community, calling attention to a form of collective social exclusion that has become broadly normalised in Irish society. ${ }^{4}$ The stereotypes and inequalities experienced by the Travelling community are interrogated through 
the character of Choppy Nagle, a gifted amateur physicist who lives in a caravan near Limerick. ${ }^{5}$ In one particularly farcical sketch, Choppy is seen filming an intimidatory "call out", a kind of video posted online by some members of the Travelling Community in order to intimidate rival families and assert their dominance. Rather than target a rival Traveller figure, however, Choppy uses the video to call out prominent physicist celebrity Brian Cox, using his caravan as a whiteboard to document his new theory on sub-atomic particles as he accuses the scientific community of trying to silence his research. By caricaturing the Irish Travelling Community and their customs in this manner The Rubberbandits are pointing to the positive contributions this community could make to Irish society were it not for the stigmatisation and social barriers that prevent their participation in the public sphere. In a way, this absurdist sketch is itself a "call out" of sorts, drawing attention to the widespread prejudices that make such a scene appear irrational, and thus comedic, to viewers. Through absurdist caricature The Rubberbandits are calling attention to the audience's own unconscious prejudices, and are encouraging an interrogation of the stereotypes associated with the Travelling Community. Given the low-levels of second level education completed by members of the Irish Travelling Community (Kenny, McGinnity, Russell and Watson), The Rubberbandits use their absurdist satire to suggest that a promising Traveller physicist is someone to be celebrated and encouraged, not laughed at. Adding to the overall absurdity of this sketch are the prosthetics worn by Bob McGlynn when portraying Choppy Nagle. These prosthetics serve to exaggerate the character's facial features to a near caricaturist degree, supplying him with a bulbous and crooked nose, alongside an accentuated and bumpy forehead that together suggest a history of blows to the face. Despite these stereotypical implications, the inflated and overdrawn nature of Choppy's facial features also suggest a certain unreality or hyperbolisation that serves to undercut the validity of the stereotypes associated with Choppy as a member of the Travelling community. By associating these stereotypes with such an unrealistic and exaggerated character, The Rubberbandits attempt to throw a wedge between stereotypes and the real lives and experiences of the Travelling Community.

These kinds of absurdist and heavily exaggerated characterisations play an important role in the satirical work of The Rubberbandits precisely because of their ability to undercut the very stereotypes they are predicated on. We see similar absurdist characterisations in "The Rubberbandits’ Guide to 1916”, a mockumentary commemorating the 1916 Rising, throughout which renowned Irish literary figures Joyce, Beckett, and Wilde are caricatured through the use of puppets. These distorted representations of Irish cultural icons, similar to those used in shows like Spitting Image and Les Guignols de l'Info, are in stark contrast to the romanticised images perpetuated of these literary figures in Irish society. The Rubberbandits employ these literary puppets as a means of interrogating the popular image of Ireland as a land of "saints and scholars" and its relevance to a contemporary Irish society. Rather than represent Ireland's sophisticated literary tradition, through their crude use of language, and their propensity for rowdy, drunken behaviour, Joyce, Beckett, and Wilde come to embody the stereotypical drunken Irishman. By bringing together contradictory conceptions of Ireland and its people in the form of these literary figures, The Rubberbandits are pointing to the inconsistencies of Irish national identity, and reveal a reality that contrasts with the national image Ireland aims to project. Moreover, the consumerist and fame-obsessed puppets also call into question the relevance of tradition and cultural heritage to a contemporary Irish society, implying the superficiality of the displays of Irish national identity that characterised the 1916 commemorations. In this manner, the duo engage absurdist satire, caricature, and stereotypes as a means of problematising dominant discourse surrounding Irish identity and nationalism. By disrupting and problematising these discourses in this way The Rubberbandits carry out a similar kind of "political culture jamming" to that described by Warner in his analysis of The Daily Show with Jon Stewart, wherein political discourse is distorted through disruptive and 
amusing editing tactics in such a way that the artifice and manipulation of contemporary political discourse can be exposed. In the case of The Rubberbandits, their disruption of these dominant articulations of Irish society and identity helps to open up a space for the interrogation of contemporary Irish society, its self-perceptions, and their place in an increasingly globalised public sphere. Moreover, by caricaturing the urban working-class, as well as the Irish Travelling Community, The Rubberbandits are challenging the myth of an all-prosperous Celtic Tiger Ireland, by pointing to social divisions that have rendered this prosperity out of reach for many members of Irish society and left them vulnerable following the economic crash.

\section{Social Commentary and the Cross-Media Presence of The Rubberbandits}

Although their absurdist interrogation of Irish social issues is certainly intriguing, it is worth noting that The Rubberbandits rose to prominence during a time when absurdist satire was experiencing somewhat of a resurgence in the Irish entertainment landscape. Although the absurdism of The Rubberbandits is certainly unique as a result of their distinctive Limerick personas, their initial popularity can be best understood when we take into account the broader rise of what Boland refers to as "economic satire" following the post-2008 economic downturn (448). Boland notes that during this difficult and uncertain period the absurdist world-view of satire was utilised to not only ridicule and critique the Irish political and financial systems, but also Irish society more broadly. This "economic satire" not only portrayed Irish politicians as openly-corrupt, but the Irish public too were lampooned through the use of stereotypes, depicted as being blindly faithful to this corrupt political system (Boland 448). Although The Rubberbandits rose to prominence during this period, Boland does not discuss their work in his analysis, though they certainly share the absurdist world-view he describes. What is notable, however, is that The Rubberbandits have outlived many of the other satirical shows and comedians discussed by Boland, and have remained prominent figures in the Irish media industry.

This is where the satirical works of The Rubberbandits are most noteworthy, as they have successfully remained a popular comedic act with Irish audiences while also cementing themselves as serious social and political commentators. Despite always embodying their satirical personas, The Rubberbandits have become prominent and respected social commentators in the Irish media, with Blindboy, in particular, being heralded as a much-needed voice of reason in Irish social and political discourse (O’Neill). ${ }^{6}$ Most interesting, however, is that the specific configuration of satire and serious commentary employed by the duo shifts depending on the particularities of the medium, platform, or format with which they engage, and as their influence as social commentators has grown, the duo have sought out new platforms which allow more freedom and control. Moreover, while their earlier work conformed to the absurdist satirical landscape of a post-crash Ireland, as Ireland's economy stabilised and its society moved past the difficulties of the financial downturn, The Rubberbandits have adjusted their satirical style to accurately respond to a steadily recovering economy and a seemingly stable social sphere. Thus, not only have The Rubberbandits adjusted their satirical style to best befit their shifting socio-political environment, but they have also sought out new platforms and mediums that better accommodate these stylistic changes. And it is this capacity and willingness to evolve as both comedians and social commentators that has helped to preserve their popularity with Irish audiences.

In order to chart the duo's progression as socially and politically critical artists, it is important to note the limitations they faced during the period in which they debuted, specifically in terms of the realities of Ireland's political climate at the time, as well as the particularities of the media and platforms with which they engaged. Much of The Rubberbandits' earlier work is largely farcical in tone, with social commentary only ever being implied rather than explicitly 
expressed. Their skits on Republic of Telly, for example, may have used imagery, stereotypes, and jokes to hint at a critical social awareness, but these works never offer any kind of outright critical perspective for their audience. However, this emphasis on farcical comedy seems logical when we consider that this work was made within the absurdist media sphere outlined by Boland; as an up-and-coming comedy duo, The Rubberbandits worked within the formal structures of Ireland's entertainment industry in order to grow their audience, and thus adopted and perpetuated the absurdist world-view that dominated Irish satire at this time. Serious commentary was rendered futile in this absurdist media environment, and it was only through an engagement with the irrational that The Rubberbandits could participate in public discourse. In this manner, we see that their output from this period, such as the aforementioned "Horse Outside," or their various skits on Republic of Telly and Channel 4, engage with contemporaneous issues surrounding machismo culture, mental health issues, and the social consequences of a recession, but do so in a purely a satirical and absurdist manner. However, this early emphasis on absurdist comedy is also due in part to the specificities and restrictions of the skit/music video/YouTube format they employed. Their Republic of Telly skits, for example, doubled as YouTube content for RTÉ, and their music videos also gained the most traction on this platform. The average length for a YouTube video at the time that these skits and videos were made was 3 minutes (van Dijck) and thus, in order to succeed on the platform, The Rubberbandits needed to adhere to its governing structures, operating within a restricted time-limit. Moreover, the diversity of content available on YouTube means that outlandish comedy is more likely to stand out to users and gain attention than serious commentary.

In contrast to these shorter videos, their mockumentary series with RTÉ afforded the duo more time and freedom to explore serious social and political issues. The socio-political climate during which these series were made was also markedly different to their earlier work. In contrast to the feelings of uncertainty and hopelessness that defined Irish society in the wake of the 2008 economic downturn, Ireland was undergoing a notable recovery in 2016, and the country was in the process of rebranding itself as an innovative tech-hub, with companies such as Facebook, Google, and Apple expanding their operations in the country (Daly; Smyth). This national rebranding also coincided with a time of important national reflection: in 2016 the 1916 Rising Commemorations marked the centenary of the failed uprising that would propel Ireland's War of Independence. As Ireland recovered from the recession, its social and political spheres stabilised, and rational discourse returned to the public sphere once more. This, in turn, allowed The Rubberbandits to include more serious commentary in their work. However, absurdist satire remained an important element in their comedy, as it also allowed them to articulate and interrogate the various contradictions that arose during this period of national reflection and renegotiation.

While the tone of their RTÉ series is still largely absurdist, the mockumentary aesthetic allows for a combination of both satirical comedy and serious commentary. Crucially, The Rubberbandits' mockumentary series offer a counter-commentary to the official narrative of both Irish history and contemporary Irish society. While the "The Rubberbandits' Guide to 1916” is a largely absurdist re-imagining of the 1916 Rising, Blindboy and Mr. Chrome also offer serious commentary on the complex history of Irish independence. For example, toward the end of the mockumentary, the duo read out their own, revised version of the Proclamation of the Irish Republic, noting that the optimism and equality declared in the original 1916 version has "nothing to do with today's Ireland”. The Rubberbandits' proclamation declares the right of the Irish people to equality and freedom, to a just and honest government, and to adequate healthcare. However, the reading of this proclamation is accompanied on screen by a montage depicting police violence, corrupt politicians, and homelessness, thus undercutting their optimistic decree. This montage also interrogates the official history of the Irish Republic, emphasising the mistreatment of the Irish people at the hands of conservative governments and 
the Catholic Church, and ultimately suggests that an independent Ireland has failed the legacy of the 1916 Rising.

While their mockumentary series do contain some notably overt political statements, such as their call to repeal the Eighth Amendment in "The Rubberbandits Guide to Sex", much of the social commentary in these series remains indirect, with their satirical comedy pointing to prominent issues, but never fully engaging with them. ${ }^{7}$ This is, in part, due to the constraints of working within the formal television industry, with Blindboy noting that much of their work was altered considerably during their time with RTÉ (Fitzpatrick). The duo have also argued that their RTÉ series never received much initial attention due to a lack of creative control on their part, and it is only through engaging with online platforms that they have been able to locate and maintain a significant audience (Fitzpatrick). While the duo create content specifically for their social media accounts, they also use them as spaces to share video clips from their work with larger networks. This practice of making certain scenes or skits available online is commonplace, and Dawson has noted that this "unbundled" content soon becomes a mobile entity that spreads independently of its source. By sharing certain skits and scenes from their RTÉ content online The Rubberbandits have been able to reach a wider audience outside the confines of broadcast television.

Most notably, social media such as Twitter and Instagram have allowed the duo to curate a loyal, niche audience, who share the same political and social outlook. As they no longer need to appeal to the mass audience of RTÉ or other television stations, The Rubberbandits have been able to use social media as a space for overt social and political commentary, and are able to speak directly to an audience who share their opinions and value their analysis. In this manner, they have also sought out new mediums and platforms that more readily allow for a rational engagement with public discourse. This shift in tone is also notable as it coincides with significant social changes in Ireland, with a growing number of citizen movements voicing their dissatisfaction with the social and political status-quo. As Irish society has become increasingly critical of its political sphere, so too have The Rubberbandits become more overtly engaged in this same critique. The Blindboy Podcast, for example, is entirely funded by listeners through Patreon, and contains a mixture of comedic ramblings and short stories, as well as Blindboy's own musings on prominent social and political issues, such as mental health, as well as social movements such as the recent housing protests in Dublin (BBC News; McGreevy and Flaherty; O'Brien). Although light-hearted and whimsical in tone, "The Blindboy Podcast" ultimately favours rational discussion over absurdist satire. The duo's Instagram and Twitter accounts follow a similar format; while they do feature absurdist jokes and original memes that deal with social and political issues in the duo's unique comedic style, these are also spaces in which the duo have been able to openly voice their opinions on a range of domestic and international issues. By embracing social media and niche-media forms such as the podcast or memes in this way, The Rubberbandits are able to speak directly to their audience, and are consequently better equipped to speak out for their audience in socially and politically contentious times.

\section{The Cultural Forum of The Rubberbandits: A Cross-Media Carnival}

But this cross-media presence is not without its shortcomings, as the dispersal of the duo's content across multiple platforms means that the full breadth of their social and political commentary can only be grasped if one engages with the full extent of their cross-media presence. In particular, the intense absurdity of their earlier work means that The Rubberbandits risk carrying out what Aitaki refers to as "satiric misfire", where a failure to engage satire's critical arsenal causes satirical works to instead become a palliative tool, rather than a source of critical engagement (79-80). In cases of satiric misfire humour instead serves to soften reality for the viewer, to make it more palatable in such a way that it also clouds a real understanding 
of the issues it seeks to address. In fact, it is exactly this kind of satiric misfire that Boland identifies as the main shortcoming of the economic satire so prevalent in the Irish social sphere following the 2008 financial crash. For Boland, the pervasiveness of this all-encompassing satire is problematic, as it fosters a cynicism on the part of its audience, who are also targeted and mocked as members of the Irish public, instead of promoting a critical engagement with the issues at hand (453-4). Rather than create an awareness of the need for critique, Boland argues that in this case the absurdism of satire is accepted as truth, a sort of self-fulfilling prophecy that serves to perpetuate rather than counter political corruption and social issues (453-4). In short, Boland argues that this absurdism becomes incorporated into the nation's selfimage and becomes a justification for these prevailing conditions, rather than a cause for corrective action. In a similar manner, if one were to only engage with the overtly absurdist works of The Rubberbandits one might come to accept the surface reality they portray where Irish society is an openly irrational, difficult, and unreasonable place.

If we take, for example, the duo's examination of mental health issues and machismo culture in Irish society, these are topics that they have frequently treated in an entirely absurdist and comedic manner. Their songs "Dad's Best Friend" (21 January 2014) and "I Wanna Fight Your Father" (25 February 2011) exploring these issues through a comedic lens without offering any criticism or overt commentary. The 2014 song "Dad's Best Friend” explores both of these issues, telling the story of a middle-aged man driven towards an existential crisis as he struggles under the expectations of an aggressively machismo culture, a post-recessionary economy, and his own "ever-diminishing youth" (Mr. Chrome). The music video features the song's protagonist driving in his car as he recounts his familial woes, his battle with suicidal thoughts, and his aggressive behaviour. We watch as he cries to a prostitute about his difficulties, as he steals drugs from his nephew's friend, and as he acts out at his work's AGM having taken the stolen drugs with his co-workers. While driving the protagonist becomes increasingly aggravated and tense as he sings the song's chorus, which hinges on the idea that rowdy and illegal behaviour, like the drug-fuelled stag night in Amsterdam the song describes, is a rite of passage necessary to cement one's manhood. As the incidents and habits described by the protagonist grow in their intensity and outrageousness, so too does the protagonist become increasingly tense and angry, growing red and strained in the face as he sings. Soon, his anger causes him to morph, taking on alien-like facial features with large, black oblique eyes and an oversized cranium. The message sent here is that the pressures of these restrictive and machismo definitions of manhood have made the protagonist an alien to himself and to society. While these machismo traditions may be mocked, their place in society is not necessarily questioned by The Rubberbandits in this piece.

Similarly, while their song "I Wanna Fight Your Father" explores how young, working-class men seek to prove their manhood through violence, it does so in a purely comedic manner, depicting the duo as they prepare for a fight by boxing a raw chicken and making a protein shake out of raw eggs, an Irish flag, and a packet of cigarettes. Like much of their earlier work, these songs and videos carry implicit critical insights into the problematic yet taken-forgranted realities of Irish society, but do little to foster a reconsideration of the role played by these questionable norms more broadly. By pointing to problematic social and political conditions in these absurdist skits and videos, but failing to overtly condemn them, The Rubberbandits risk further contributing to this same culture of socio-political cynicism noted by Boland that would dismiss rather than attempt to tackle the issue of mental health problems in Irish society. In this sense, only engaging with these absurdist videos could serve to naturalise the idea that mental health issues can be dismissed, and working-class males are social deviants who only stand to be mocked.

However, if one engages with their work across different mediums and platforms, and if one approaches their content on both a conscious and critical level, these social issues can be 
explored in different ways, thus allowing for an engagement with different ideological positions. For example, Blindboy Boatclub's podcast series “An Introduction to Cognitive Psychology" gives a very different, and very serious perspective on mental health in Irish society, and takes a proactive approach in helping to address this issue. In the first instalment of this series Blindboy tells his listeners about his own experiences with mental health issues, and details how cognitive behavioural therapy helped him to recognise and address the internal and automatic behaviours that contributed to his mental health issues. Blindboy then describes to his listeners tactics they can use to recognise how their own "toxic thoughts" contribute to a "feedback loop of negativity", and how they can tackle these thoughts in a way that will improve their mental and emotional health. Central to this process, he argues, is changing one's beliefs about certain triggering events in a way that fosters rational responsive thinking.

Although Blindboy speaks casually throughout this podcast, cursing occasionally and audibly vaping as he speaks, his tone overall remains serious and at no point does he treat mental health issues in a light-hearted or comical manner. In fact, later in this episode Blindboy notes that many people missed the irony of their earlier songs and took their lyrics and music videos at face value, which is one of the reasons why the duo have distanced themselves from some of their earlier work. But more than just distance themselves from their earlier, more controversial work, the prismatic structure of their cross-media presence has allowed the duo to develop their social and political commentary in more nuanced ways, and invites both a broader audience and a broader set of interpretations of their social and political themes they explore. In this manner, if we look at the treatment of these issues across their various media profiles and content, we can see that a much more serious and rational discourse is also taking place. The cross-media presence of The Rubberbandits allows them to not only cultivate a biting satirical lens through which social, political, and economic issues can be exposed, but also offers the opportunity for a serious engagement and interrogation of these issues once the initial expository jolt of their satirical works has worn off. The challenge for The Rubberbandits, then, is to entice their audience to participate in the full-breadth of their cross-media presence, so that they might be exposed to a more complete and developed socio-political critique.

Although the cross-media presence of The Rubberbandits has the potential to undercut this risk of satiric misfire by allowing them to adjust both the tone and seriousness of their work, this potential can only be harnessed if their cross-media presence is an inviting space for audiences and social media users. Central to the appeal of The Rubberbandits cross-media presence is its dynamic and carnivalesque nature. Its carnivalesque qualities lie in its ability to utilise chaos and humour in a constructive and liberatory manner, in such a way that it creates a non-hierarchical and transgressive social experience where traditional structures and norms can be subverted and freedom can take root, albeit momentarily. This concept of the carnivalesque was first explored by Bakhtin who noted that the carnival utilised the playful, the excessive, and sometimes the grotesque in order to create a communal experience where the audience can enter into a dialogue with the performance, creating a space for discussion and subversion. This same subversive and creative energy can be recreated outside of the carnival itself, with the chaotic and grotesque humour characteristic of the carnivalesque also finding expression in literature, film, television, and even activist demonstrations. The absurdist satire of The Rubberbandits, in combination with their cross-media presence, functions in a similar manner, providing a space where societal norms are not only mocked, but also interrogated and debated collectively. Most importantly, where the exaggerated, absurd, and sometimes offputting characterisations of The Rubberbandits offer new perspectives to their audience, their cross-media presence creates a virtual yet communal space for the active participation of their audience in the expression of ideas and the interrogation of social and political issues.

Crucially, the carnivalesque qualities of The Rubberbandits' online platforms mean that their cross-media presence takes on an important forum-like function, one that allows them 
to incorporate and address a variety of different issues and perspectives, and that provides a space where their audience can negotiate their understanding of contemporary Irish experience. The multiplicity of perspectives offered through The Rubberbandits' cross-media presence is is crucial to understanding the duo's enduring popularity with Irish audiences, as well as their transition toward more serious forms of social commentary. The ability of different media to function in a forum-like way has already been established elsewhere, with Newcomb and Hirsch arguing that the ideological multiplicity of broadcast television gives audiences the opportunity to reflect upon various ideological issues and societal contradictions. With this in mind, Newcomb and Hirsch argue that television functions as a kind of "cultural forum", offering a complex and oftentimes contradictory perspective on prominent social discussions, with opposing meanings and opinions often abutting one another within the forum's flow. Mediated cultural forums of this nature become important spaces for social interpretation, allowing audiences to negotiate reality through their exposure to a variety of ideological positions. In a similar manner, the varying levels of engagement offered by the cross-media forum of The Rubberbandits also allow it to operate as a space for the negotiation of reality. Their crossmedia presence is a constellation of sorts, with different platforms and mediums intersecting in different ways, and the various social and political themes they explore are represented in different manners across this prismatic forum. An engagement with different facets of The Rubberbandits' cross-media presence, then, has the ability to open up new perspectives and new forms of interpretation.

Of course, many of the forum-like qualities of The Rubberbandits' cross-media presence are a result of the various social media platforms they engage with. Although The Rubberbandits' absurdist satire might spark debate, the ability of their audience to participate in this social interrogation hinges on the communicative tools provided by social media: members of their audience can submit questions directly to Blindboy's podcast via email, they can share the duo's content on their own accounts, message the duo directly on a number of social media platforms, and, most crucially, they can comment on the duo's social media postings. In this way, fans, viewers, and even detractors can discuss both with the duo and amongst themselves the issues and topics touched on in their work. A particularly illustrative example of such discussions arose following the Irish General Election in January 2020, where controversial left-wing republican party Sinn Féin saw a surge in voter support (O’Leary). When Blindboy posted to The Rubberbandits Facebook page about foreign press misrepresenting the reasons behind Sinn Féin's sudden rise in popularity, Facebook users gathered to comment under this post, debating whether or not this surge was a form of populism, a protest vote, or simply a widespread desire for political change (Rubberbandits). Many of those commentating did not explicitly agree with Blindboy's stance on the matter, but all the same this post became a space for debate and the negotiation of ideas. Most importantly, through their social media interactions, the audience's own opinions and interpretations became a part of the ideological multiplicity of The Rubberbandits' cross-media forum, offering up new perspectives to other members of the public, consequently allowing these discussions to grow beyond the duo themselves. This is where we see the carnivalesque qualities of The Rubberbandits' cultural forum come to the fore. By embracing the new forms of communication offered by social media the duo have allowed for a more free, diverse, and direct communication between their viewers on prominent social issues, and their absurdist style eschews social norms in favour of obscene absurdity.

However, while it has been argued that social media have the capacity to form new democratic public spaces that allow a wide range of people to participate in political discussion (Park), this public space is also limited to the users of any particular platform. The cross-media forum of The Rubberbandits is significant, then, in that it has the capacity to generate discussion and influence public opinion across mediums and platforms. Bakhtin suggests that the demise 
of the carnival has limited the public's ability to engage in an active critique of traditional hierarchies, thus reserving this function for the satirist alone (Bakhtin, as cited in Boland). However, by engaging with a variety of media forms The Rubberbandits have established a cross-media forum that invites their audience to engage in an interrogation of dominant social and political discourse, thus allowing for the return of a carnivalesque public space. Crucially, The Rubberbandits are ever expanding their cross-media profile, incorporating new social platforms in order to maintain their public presence. If the liberatory and subversive capacities of the carnival have always been contingent on its public nature, then it is only logical that in order to preserve their role as social commentators, The Rubberbandits must consistently seek out new digital spaces of public assembly and interaction. It is through this lens that we can best understand Blindboy's recent decision to begin livestreaming on the increasingly popular website Twitch (Golby), capitalising on the site's growing user base in order to bring his absurdist humour and political commentary to a space where the public are already gathering digitally.

This is ultimately the key to The Rubberbandits' enduring popularity and relevance; they continually expand their media presence into new digital "public spaces", ensuring the continued visibility of their absurdist satire in the public sphere, which in turn allows them to turn these spaces of digital gathering into welcoming and non-judgemental spaces of social interrogation and debate. By "following the public" in this way, The Rubberbandits have been able to guarantee the success of their cross-media presence while also fostering critical social discourse among their audience. By taking their satire and social commentary to a (largely digital) public, and by creating an enticing and exciting carnivalesque space through their absurdist humour, The Rubberbandits are able to invite members of the public to participate in their social and political debates, thus using their cross-media presence to a construct a dynamic and multifaceted cultural, social, and political forum.

By seeking out new mediums and platforms that allow for a more varied engagement with prominent social and political issues, The Rubberbandits have been able to adapt their satirical style to suit changing socio-political contexts. Consequently, the duo are better equipped to respond appropriately in ways that speak to the lived experiences of their audience. For example, their commentary on the Irish housing crisis has been openly critical and serious in tone, with Blindboy taking to social media like Twitter to discuss the implications of high rents and poor quality housing on the mental health of young renters in Ireland (The Blindboy Podcast). In contrast to this very rational discourse, Blind Boatclub’s 2019 BBC Three series, "Blindboy Undestroys the World," takes a much more absurdist approach to the UK's own housing issues, featuring game-show style skits that seek to emphasise the challenges faced by young renters across the UK, highlighting issues such as hidden rental charges, sex-for-rent agreements, and unsanitary living conditions. The difference in Blindboy's approach to these very similar issues lies in the different socio-political contexts in which his commentary is operating; if we take into account the rational and democratic discourses that have defined Irish social movements in recent years, a serious treatment of the Irish housing crisis is a more suitable approach for this particular socio-political climate. However, in the British context, given the sense of irrationality and unpredictability that has come to define the social and political climate during the ongoing Brexit negotiations, an absurdist treatment of such a prominent social issue becomes the most appropriate form of response. Crucially, The Rubberbandits are able to speak to these different socio-political situations simultaneously, offering a gateway to criticism and debate that is tailored to the specific needs of their various audiences. 


\section{Conclusion}

Although The Rubberbandits have certainly grown and matured as artists since their prank-call days, a playful and absurdist outlook has continued to define their work, both as comedians and as social commentators. Even when broaching serious issues, The Rubberbandits, and Blindboy Boatclub in particular, are always characterised by a jocular spirit and a roguish use of language that helps to subvert the traditional dynamics of the artist/audience relationship. Despite their shift towards a more serious form of socio-political commentary, the absurdist humour and outlook that remains constant in their work, and that is typified by their respective personas, allows The Rubberbandits to present their social and political opinions and criticisms in a way that is accessible, amusing, and inviting to audiences. By maintaining this playful satirical edge throughout their work The Rubberbandits are able to use their absurdist humour as foundational tool that fosters a carnivalesque relationship with their audience across the various media they engage with, one that is premised on debate and participation, and that allows them to present their socio-political criticisms in way that is neither moralising nor prescriptive. By engaging with a variety of different media and platforms, and by adjusting the specific configuration of satire and serious commentary to suit the demands of these different media, The Rubberbandits have been able to transition to the role of respected socio-political commentators without alienating their existing fans, all the while allowing them to reach a broader audience.

By both embracing and adjusting to the dynamic nature of their cross-media environment the duo are consequently better equipped to keep up with and engage their audience in a range of social and political issues. Most notably, by seeking out spaces of digital assembly the duo have been able to utilise their absurdist tendencies as a means of establishing a dynamic and carnivalesque cross-media forum that invites their audience to challenge dominant discourses and to engage critically with social and political issues. In a specifically Irish context, The Rubberbandits are able to encourage their audience to interpret and negotiate the reality of Irish experience on their own terms. In this sense, it seems that The Rubberbandits hope to return to the Irish people their capacity to subvert dominant power structures and allow them to maintain a critical consciousness through an engagement with their cross-media presence. Given the surge in citizen movements in Ireland of late, it seems an important public renegotiation of Irish identity and society is taking place. In this climate, an effective crossmedia forum could be particularly influential in impacting public opinion and generating impactful social change.

\section{Notes}

1 "Gas cunt" is a phrase commonly used in Ireland to describe a humorous person. It is most often used in an endearing manner. According to Blindboy Boatclub a "gas cunt” is “a specific type of funny person. It's almost like if a person's humour appears to be quite dark or something, a bit stupid. 'Gas cunt' suggests a depth behind whatever it is they're speaking about” (Boatclub).

2 It is also worth noting that, since 2010, Limerick has had the highest suicide rate in Ireland, with incidents much higher among young men and socially disadvantaged groups. This relates to Blindboy's own mental health activism, and his work with The Rubberbandits seeks to highlight the social and economic circumstances that have exacerbated mental health issues in both Limerick and Irish society more broadly (The Irish Times; Suicide n.d.). 3 Balaclavas are readily associated with paramilitary groups and the sectarian violence of the Troubles. By fashioning balaclavas out of plastic bags the duo are alluding to Ireland's difficult republican history, while also suggesting that the new "Irish Struggle" is one against the increasing irrationality of Ireland's social and political spheres. The Irish people must now fight for both a fair society and an inclusive form of economic stability, rather than for national identity or independence.

4 The Irish Travelling Community are an indigenous and historically nomadic minority with distinct cultural and linguistic traditions. The Travelling Community face frequent discrimination, exclusion, and prejudice in Irish society, and do not have the same access to education and healthcare as the "settled community" (Conway; Irish 
Traveller Movement n.d.).

5 Choppy Nagle appears in both their prank phone-calls, as well as their pilot episode filmed for Channel 4.

6 Blindboy himself has acknowledged this dichotomy, suggesting that his audience need to question why it is that a plastic-bag wearing comedian is making more sense than the Irish political sphere (Channel 4 News).

7 The Campaign to Repeal the Eighth Amendment sought to amend the section of the Irish constitution dealing with the termination of pregnancy. By repealing the eighth amendment to the constitution, which recognised the equal right to life of the mother and the unborn, the campaign sought to introduce comprehensive legislation on the termination of pregnancy. A referendum was held on 25 May 2018 and the introduction of legislation was approved by $66.4 \%$ of voters (McDonald and Graham-Harrison).

\section{Works cited}

Aitaki, Georgia. "Laughing with/at the National Self: Greek Television Satire and the Politics of Self-disparagement.” Social Semiotics 29.4 (2019): 68-82. DOI: https://doi.org/10.1080/10350330.2017.1408893

Bakhtin, M. Rebelais and His World. Bloomington: Indiana University Press, 2009.

BBC News. "KBC Bank Protest Stages by Irish Politicians over Evictions.” BBC News 20/12/2018. 15 Jan 2019. https://www.bbc.com/news/world-europe-46626093

Bergson, Henri. Laughter: An Essay on the Meaning of the Comic. Rockville: ArcManor, 2008.

Boatclub, Blindboy. "Shovel Duds." The Blindboy Podcast. Podcast audio. November 15, 2017.

Boland, Tom. “Critical Comedy: Satire, Absurdity and Ireland's Economic Crash.” Irish Political Studies 27.3 (2012): 440-56.

Brillenburg, Kiene. "Spitting Image and Pre-Televisual Political Satire: Graphics and Puppets to Screens.” Image [\&] Narrative 12.3 (2011):113-36.

Buck-Morss, Susan. “Aesthetics and Anaesthetics: Walter Benjamin's Artwork Essay Reconsidered.” October 62 (1992): 3-41.

Carr, Aoife. “Rubberbandits Profess X-Factor Ignorance.” The Irish Times 15/12/2010. 1 Sept 2020. https://www.irishtimes.com/news/rubberbandits-profess-X-factor-ignorance1.868855

$\begin{array}{llllll}\text { Channel } 4 & \text { News. } & \text { Twitter } & \text { Post. } & 24 & \text { March }\end{array}$ https://twitter.com/Channel4News/status/713078651835658240

Crines, Andrew Scott. "Rhetoric and Satire - Spitting Image and Political Comedy." Rhetoric in British Politics and Society, Ed. J. Atkins et al. Basingstoke: Palgrave Macmillan, 2014:149-59.

Conway, Brian P. “Traveller Horses, Local Authorities and Public Policy in Contemporary Ireland.” Nomadic Peoples 8.1 (2004): 65-79. DOI: https://doi.org/10.3167/082279404782066104

Cowan, Rosie. "Gangs of Limerick: a Bloody Four-year Story of Shooting, Kidnapping and Revenge.” The Guardian 31/01/2003. $10 \quad$ Feb 2019. https://www.theguardian.com/world/2003/jan/31/ireland

Daly, Sharon. “The Rise of Dublin’s Silicon Docks.” IFSC.ie, International Financial Services Centre. 21 Jan 2019. https://www.ifsc.ie/feature.aspx?idfeature=167430

Dawson, Max. “Little Players, Big Shows: Format, Narration, and Style on Television's News Smaller Screens.” Convergence 13.2 (2007): 231.

Fitzpatrick, Richard. “Blindboy Sees the Light.” The Irish Examiner 02/04/2018. 14 Jan 2019. https://www.irishexaminer.com/lifestyle/arid-30835247.html

Golby, Joel. “Trigger Happy: the Amazing Rise of Twitch.” The Guardian 08/09/2019. 26 Aug 2020. https://www.theguardian.com/global/2019/sep/08/how-did-twitch-become-asbig-as-youtube-by-live-streaming-video-game-players 
Irish Traveller Movement. “About Irish Travellers.” 18 Jan 2019. https://itmtrav.ie/what-isitm/irish-travellers/

Kaplan, Leah. "A New Theory About the Brontosaurus: Humor as Absurdity and the Violation of Expectations in Monty Python’s Flying Circus.” Electronic Thesis or Dissertation. University of Cincinnati, 2010. https://etd.ohiolink.edu/

Kenny, Oona, Frances McGinnity, Helen Russell and Dorothy Watson. “A Social Portrait of Travellers in Ireland.” Economic \& Social Research Institute 17 Jan 2017. DOI: https://doi.org/10.26504/rs56

McDonald, Henry and Emma Graham-Harrison. "Ireland Votes by Landslide to Legalise Abortion.” The Guardian 26/05/2018. 15 Jan 2019. https://www.theguardian.com/world/2018/may/26/ireland-votes-by-landslide-tolegalise-abortion

McGreevy, Ronan and Rachel Flaherty. "KBC Bank Branches Attacked amid Protest Outside Dublin Headquarters.” The Irish Times 22/12/2018. 15 Jan 2019. https://www.irishtimes.com/news/crime-and-law/kbc-bank-branches-attacked-amidprotest-outside-dublin-headquarters-1.3740721

Mr. Chrome. "Behind the Joke: Rubberbandits, Tony Law and Mark Lucero on Their Comedy.” The Guardian 16/04/2014. 18 Aug 2020. https://www.theguardian.com/stage/2014/apr/16/behind-the-joke-rubberbandits-tonylaw-marc-lucero

Newcomb, Horace M., and Paul M. Hirsch. “Television as a Cultural Forum.” Television: The Critical View, Ed. Horace M. Newcomb, 6th edition. New York: Oxford University Press, 1994.

O’Brien, Tim. “Thousands March in Homelessness Protest in Dublin.” The Irish Times 01/12/2018. 15 Jan 2019. https://www.irishtimes.com/news/ireland/irishnews/thousands-march-in-homelessness-protest-in-dublin-1.3717301

O’Leary, Naomi. “Sinn Féin Surge Makes Irish Political History.” Politico.eu 09/02/2020. 21 Sep 2020. https://www.politico.eu/article/sinn-fein-surge-makes-irish-political-historyirish-election-3-way-tie

O’Neill, Elaine. "Blindboy from The Rubberbandits Absolutely Nailed it on the Late Late Last Night.” The Daily Edge 9/01/2016. 12 Jan 2019. https://www.thejournal.ie/rubberbandits-2-2-2539343-Jan2016/

Park, Chang Sup. "Political Carnivalism and an Emerging Public Space: Examination of a New Participatory Culture on Twitter.” Int. J. Electronic Governance 6.4 (2013): 302-18.

Rubberbandits (@TheRubberbandits). Re The Sinn Fein success in the polls. Facebook post, 09/02/2020, 12:35pm, $21 \quad$ Sep 2020. www.facebook.com/TheRubberbandits/posts/10157999737342200

Scripnic, Gabriela and Diana Elena Popa. "From Hostile Humour to Stereotyping in Televised Satire Les Guignols de l'Info.” Language and Dialogue 5.1 (2015): 90-106.

Smyth, Jamie. "Dublin Becomes Hub for Major Internet Groups." Financial Times, 27/10/2011. 21 Jan 2019. https://www.ft.com/content/836bffd0-00a8-11e1-930b00144feabdc0

"Suicide." National Suicide Research Foundation. $10 \quad$ Jan 2019. https://www.nsrf.ie/statistics/suicide/

The Blindboy Podcast (@Rubberbandits). “The Housing Crisis Needs to Be Viewed as a Health Emergency at This Point.” Twitter, 24/05/2019, 10:53am, 25 Sep 2020. https://twitter.com/rubberbandits/status/1131845737476775937?lang=en

“The Irish Times View on Suicide Patterns: and Urgent Situation.” The Irish Times 22/05/2018. 10 Jan 2019. https://www.irishtimes.com/opinion/editorial/the-irish-times-view-onsuicide-patterns-an-urgent-situation-1.3503316 
Warner, Jamie. “Political Culture Jamming: The Dissident Humor of The Daily Show.” Popular Communication 5.1 (2007): 17-36.

Weiner, Robert G. "Peter Delpeut's The Forbidden Quest: History and Truth in Fiction.” Too Bold for the Box Office: The Mockumentary from Big Screen to Small, Ed. Cynthia J. Miller. Lanham, MD: Scarecrow Press, 2012: 35-50.

van Dijck, José. "Youtube Beyond Technology and Cultural Form.” After the Break: Television theory today. Edited by J. Teurlings and M. de Valck. Amsterdam: Amsterdam University Press, 2013: 147-159.

Vaughan, Elaine and Máiréad Moriarty. "Voicing the 'Knacker': Analysing the Comedy of the Rubberbandits.” Voice and Discourse in the Irish Context, Ed. Diana Villanueva Romero, Carolina P. Amador-Moreno, and Manuel Sánchez Garcia. London: Palgrave Macmillan, 2018: 13-45.

Received: 10 October 2019

Revised version accepted: 1 September 2020

Faye Mercier is a graduate of the Research Masters in Media Studies programme at the University of Amsterdam. With a specialisation in television and cross-media culture, her work focuses on the media industries of Ireland, Japan, and South Korea, paying particular attention to both the sociocultural implications and the socioeconomic resonances of various media content. Prior to her graduate studies she obtained a degree in Film Studies from Trinity College Dublin, where she was first introduced to the study of Irish media. In recent years she has analysed Brexit as a media phenomenon, paying particular attention to discussions and depictions of the "Irish Border Problem". Alongside an interest in representations of Ireland on screen, she has also researched diverse topics such as K-Pop, K-Dramas, and reality television.

mercier.faye@gmail.com 